\title{
Reform of the electricity sector in Ukraine - liberalization of the market and corporatization of companies
}

ABSTRACT: Energy is a basic industry for any economy and ensures the country's security, including economic security. The purpose of the article is to analyze the reform of the energy sector in Ukraine for successful integration into the energy sector of the European Union. The state of the energy industry from 2003 to 2018 is analyzed. The following main reasons for the decrease in electricity generation in Ukraine are identified - a decrease in production volumes, the annexation of Crimea and the anti-terrorist operation in the east of Ukraine, a decrease in the volume of energy output from Thermal Power Plants due to aging capacities, difficulties with raw materials, low efficiency, which, however, has a good effect on the environment due to a decrease carbon dioxide emissions. The directions of reforming the electric power industry of Ukraine are considered in the context of "industry-market-company". Four electricity market models are analyzed and the new model of the competitor's market for electricity in Ukraine with contract market, spot market, the balancing market is substantiated. The structure of the segments of the new electricity market and the participants are proposed. More than half of the electricity market is provided by nuclear power, which ranks the $5^{\text {th }}$ in the world in terms of installed capacity. The analysis of the performance indicators of the nuclear company for 2007-2019 showed significant reserves for the company's growth, which are

Corresponding Author: Hanna Doroshuk; e-mail: doroshuk.anna@gmail.com

1 Department of Management, Odessa National Polytechnic University, Ukraine; ORCID iD: 0000-0002-0340-7514; e-mail: doroshuk.anna@gmail.com

2020. The Author(s). This is an open-access article distributed under the terms of the Creative Commons Attribution-ShareAlike International License (CC BY-SA 4.0, http://creativecommons.org/licenses/by-sa/4.0/), which permits use, distribution, and reproduction in any medium, provided that the Article is properly cited. 
being successfully implemented through strategic development projects and phased corporatization of the company as a tool of unbundling. The main challenges of implementation a new market model are analyzed and solutions are proposed.

KEYWORDS: electricity market model, liberalization of electricity market, corporatization of energy

companies, unbundling

\section{Introduction}

The energy sector is a warehouse and a lock on the social and economic development of Ukraine and any country. The vector of development of the energy sector, which is designated in the Energy Strategy of Ukraine for the period up to 2035, is the formation of an effective sector of the national economy, built up to competition in the European and public energy markets according to the Third Energy Package.

Ukraine has a well-developed electric power industry, which is represented by nuclear, thermal, solar, wind power and hydropower, in contrast, for example, to Austria, which is dominated by hydropower (Kucharska 2017). But one of their problems, as in the European Union, is the aging of capacities (Malko 2015). Historically, the European power system has a nationwide structure with a limited number of interconnections (Malko 2014). Today, the European energy system serves about half a billion people which consume over $300 \mathrm{TWh}$ per year. The high-voltage transmission network consists third of a million $\mathrm{km}$ of lines and cables. Medium and low voltage distribution networks cover about 5 million $\mathrm{km}$ of lines and cables, operated by five thousand operators in the EU. The new European climate and energy policy requires a rapid and substantial and very rapid evolutionary changes of renewable energy sources (Eid et al. 2016). And the first step for any country and for Ukraine on the path of these reforms is market liberalization.

The experience of liberalizing the Swedish energy market, which included tax reforms, shows an increase in energy security (Frączek 2012). Poland, like Bulgaria, very quickly passed the stages of market liberalization (Krzykowski 2009) and at the moment the reforms are related to forecasting and planning the demand for electricity and with the search for energy efficiency and alternative sources of electricity generation (Popławski 2012).

The successful implementation of the energy policy of Ukraine for the development of the energy sector in the field of electricity in the liberalization of the electricity market, the basis of which is strong competition and customer support; integration of the energy sector of Ukraine to the energy market of the European Union (EU); technical innovations, advances in security and efficiency. And in short - on the pillars: safety, efficiency, competitiveness (Sencar et al. 2014).

The hypothesis of the study is that the reform of the electric power industry is possible only in the context of the close interconnection of market reforms and energy companies in order to maintain safety, efficiency and competitiveness as the basic components of European energy policy. 
The aim of the paper is to analyze the reform of the energy sector as a combination of such areas as market liberalization and corporatization of energy companies.

The research questions of the paper are to study the state of the electric power industry of Ukraine; to ground the choice of a market model and identify the main challenges of such a choice; to describe strategic development projects as the implementation of energy policy and stages of corporatization of energy companies as the tool of unbundling.

\section{Analysis of the electricity industry structure of Ukraine}

Electricity is the basic and one of the oldest branches of Ukraine's economy, the date of its origin is considered to be 1872, when on July 5 the Kyiv City Council scheduled a tender for the lighting of Kyiv ( 480 lanterns). At the beginning of the $20^{\text {th }}$ century, there were attempts to build power generation stations, but significant electricity production on a permanent basis began only in the 1950s and reached its maximum in 1990-298 billion kWh (Fig. 1).

According to the data in the Figure1 for the period from 2003 to 2018, there was a decline in electricity production, which was largely due to the decline of industry and since 2014 with the anti-terrorist operation in eastern Ukraine.

If we consider the structure of electricity generation in Ukraine, we can observe the following trends:

$\checkmark$ the most of Nuclear Power Plants (NPP) only are used to cover the main part of consumption and technological regulations do not allow to participate in daily regulation;

$\downarrow$ low maneuverability of Thermal Power Plants (TPP) power units running on solidMalo fuel because of significant wear of equipment;

$\checkmark$ reduction of electricity generation of TPPs and Combined Heat and Power (CHP) is due to aging equipment, difficulties in providing raw materials due to events in the east of the country and generally benefit from the global reduction of such electricity generation, which leads to carbon dioxide emissions and the greenhouse effect;

$\checkmark$ since 2002, the generation of electricity from alternative sources has reached significant volumes and began to take this into account in the total output. To implement the new market model, it is important that the output of electricity using alternative sources is largely determined to be unregulated and variable, which is exacerbated by the lack of tools and approaches to reliable forecasting of their generation modes.

Electricity is a special commodity that cannot be stored, which in the conditions of reduced consumption leads to the fact that part of the production capacity ceases to be used.

Therefore, it is possible to obtain more electricity and sell electricity to foreign markets by complying with the sales requirements adopted in the EU. 


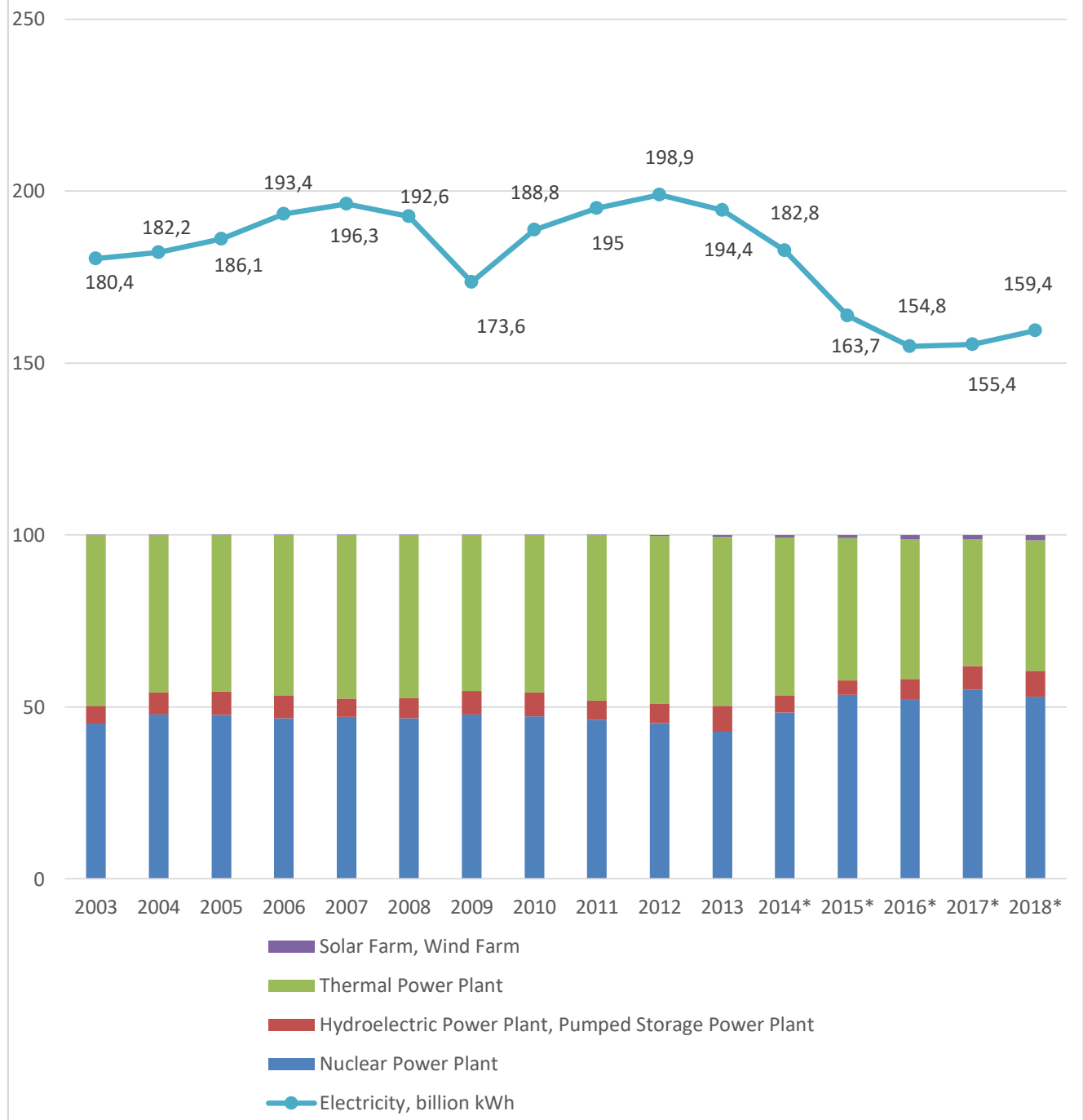

* 2014-2018 production in the Russian-occupied territory of Ukraine is not taken into account

Fig. 1. Structure and volumes of electricity production in the United Energy Systems of Ukraine for 2003-2018 [billion kWh]

Source: own study based on: Power plant capacity and electricity generation, macroeconomic indicators

Rys. 1. Struktura i wielkości produkcji energii elektrycznej w Połączonych Systemach Energetycznych Ukrainy na lata 2003-2018 [miliard kWh] 


\section{Implementation of a new open competitive model of the electricity market in Ukraine}

For more than 20 years, the EU has launched a common energy policy and energy diplomacy for all member states. Europe has made significant progress on energy security through planned and consistent work on energy legislation.

The first Energy Package was adopted in 1996, the European Union's Energy Security Act, which sets out the basic rules for the electricity and natural gas markets.

The main idea of the Second Energy Package, which was adopted by the European Parliament in 2003, was to separate the mining and marketing units from the transport arteries (so-called property unbundling). Thus, the activities of companies supplying natural gas and electricity must be separated from production and generation.

The Third Energy Package, which was adopted in the EU in 2009, is currently in force in Europe. Its main idea is the full liberalization of energy markets and the creation and operation of an Independent National Regulator for each member state of the European Union, which should regulate the activities of companies in the energy sector. Within the framework of the Energy Package, the Agency for Interaction of Energy Regulators was established, the purpose of which is to help National Regulators to fulfill their responsibilities.

The Third Energy Package, adopted in July 2009, promotes the use of renewable energy sources by creating favorable conditions for the introduction of new energy generating capacity. The main goal pursued by the European Commission in creating the Second and Third Energy Packages is to increase energy competition by entering the market of new players, which would help reduce prices. These packages also contain directives and regulations on environmental protection, energy efficiency and consumer access to statistical information on the state of energy markets (Energy strategy of Ukraine for the period up to 2035 "Safety, energy efficiency, competitiveness": approved by the Cabinet of Ministers of Ukraine from September 18, 2017. No. 605-r).

The third Energy Package provides:

$\checkmark$ separation of activities of vertically integrated economic entities,

$\checkmark$ strengthening cross-border trade in the energy sector,

$\checkmark$ creation of effective national regulatory authorities,

$\downarrow$ promoting cross-border cooperation and investment,

$\downarrow$ promoting the transparency of energy companies.

The world experience of reforming the electricity industry (Hunt and Shuttleworth 2004; Stoft 2003) has shown that the purpose of reform is:

$\downarrow$ for developed countries: reduction of electricity prices by organizing competitions in the field of generation and marketing (UK, Australia, Scandinavian countries); reduction of the difference in tariffs in different regions of the country (USA and Norway);

$\downarrow$ for developing countries: attraction of private (including foreign) investments (Chile, Argentina, Brazil); introducing competition in the supply market by giving consumers a choice of supplier. 
The main conditions for reforming the electricity industry are:

$\checkmark$ adoption of electricity legislation that clearly defines the rights and responsibilities of all stakeholders,

$\downarrow$ no requirements for radical redistribution of ownership structure,

$\downarrow$ division of vertically integrated companies by types of activity.

To create an effective competitive environment in the field of production and supply of electricity, state regulators ensure the development of: market models (Table 1), legal framework, regulatory framework, market rules (Hogan 1997; Barroso et al. 2005; Sencar et al. 2014).

TABLE 1. Comparative analysis of electricity market models

TABELA 1. Analiza porównawcza modeli rynku energii elektrycznej

\begin{tabular}{|c|c|c|c|c|}
\hline $\begin{array}{l}\text { Characteristics } \\
\text { of the model }\end{array}$ & Model 1 & Model 2 & Model 3 & Model 4 \\
\hline Definition & $\begin{array}{l}\text { Monopoly at all } \\
\text { levels }\end{array}$ & $\begin{array}{l}\text { Competition in } \\
\text { production - the only } \\
\text { buyer }\end{array}$ & $\begin{array}{l}\text { Competition } \\
\text { in production and } \\
\text { choice for distribution } \\
\text { companies }\end{array}$ & $\begin{array}{l}\text { Competition } \\
\text { in production and } \\
\text { choice for end } \\
\text { consumers }\end{array}$ \\
\hline $\begin{array}{l}\text { The structure } \\
\text { of the model }\end{array}$ & $\begin{array}{l}\text { a) vertical } \\
\text { integration } \\
\text { b) a separate retailer }\end{array}$ & $\begin{array}{l}\text { a) an integrated } \\
\text { version of the } \\
\text { distribution company } \\
\text { b) a disaggregated } \\
\text { version of } \\
\text { distribution companies }\end{array}$ & $\begin{array}{l}\text { All levels are divided } \\
\text { Spot market } \\
\text { Bilateral trade } \\
\text { agreements between } \\
\text { the manufacturer, the } \\
\text { market and the distri- } \\
\text { bution company }\end{array}$ & $\begin{array}{l}\text { All levels are divided. } \\
\text { Direct bilateral } \\
\text { agreements between } \\
\text { the producer, the } \\
\text { market, the distribu- } \\
\text { tion company and the } \\
\text { consumer }\end{array}$ \\
\hline $\begin{array}{l}\text { The main factor } \\
\text { in ensuring the } \\
\text { effectiveness } \\
\text { of participants } \\
\text { in the market }\end{array}$ & $\begin{array}{l}\text { Economies of scale; } \\
\text { delays in setting } \\
\text { tariffs by the } \\
\text { regulatory body }\end{array}$ & $\begin{array}{l}\text { Long-term contracts } \\
\text { between the } \\
\text { manufacturer and the } \\
\text { purchasing agency }\end{array}$ & $\begin{array}{l}\text { Existence of the } \\
\text { market of bilateral } \\
\text { contracts, and also } \\
\text { the financial market } \\
\text { (futures, forward) }\end{array}$ & $\begin{array}{l}\text { Existence of a market } \\
\text { of bilateral contracts } \\
\text { High degree of } \\
\text { intensity of operation } \\
\text { of available capacities } \\
\text { and introduction of } \\
\text { efficient production } \\
\text { technologies }\end{array}$ \\
\hline $\begin{array}{l}\text { Mechanism } \\
\text { of price support }\end{array}$ & Regulated tariffs & $\begin{array}{l}\text { Tariff, which is based } \\
\text { on a contract }\end{array}$ & $\begin{array}{l}\text { Competitive prices for } \\
\text { one market or bilateral } \\
\text { contracts. Regulated } \\
\text { tariffs for distribution } \\
\text { trade }\end{array}$ & $\begin{array}{l}\text { Competitive prices for } \\
\text { one market or bilateral } \\
\text { contracts }\end{array}$ \\
\hline Country & France (EDF) & $\begin{array}{l}\text { Northern Ireland, } \\
\text { Spain, China until } \\
1985\end{array}$ & $\begin{array}{l}\text { Great Britain, Norway, } \\
\text { USA }\end{array}$ & Great Britain, Norway \\
\hline
\end{tabular}

Source: own study based on (Bower and Bunn 2000; Kirschen and Strbac 2004; Hancher et al. 2015). 
The wholesale electricity market, where electricity and capacity are special goods sold separately, has been replaced by a new market with a single product (electricity, including capacity), which can be paid both at a single rate and at a double rate (Cramton and Ockenfels 2012; Green and Newbery 1992; Michalski and Sołtysik 2016).

The modern system of markets in modern electricity in Ukraine includes:

$\checkmark$ contract market based on bilateral agreements between wholesale market participants for a period of 1 week to decades. A bilateral agreement is an agreement for the purchase and sale of electricity concluded between two market participants outside organized market segments, except for the agreement on the supply of electricity to the consumer. Goods in the contract markets: electricity and capacity or only electricity;

$\downarrow$ operational (spot) market, operating within the current day, divided into periods of appropriate duration (dispatch intervals: 30 minutes, 1 hour). Trading is carried out through a pool or exchange (auction). Pool trade is an energy association that carries out wholesale purchase and sale of electricity according to the current rules of the electricity market in Ukraine. Goods in operational markets - only electricity;

$\checkmark$ balancing market, organized by the electricity transmission system operator in order to provide sufficient volumes of electric power and energy required to balance the production and import and consumption and export of electricity, settlement of systemic constraints in the unified energy system of Ukraine, and financial settlement of electricity imbalances.

The old market model provided for vertical integration "production-transmission-distribution and sales-actual consumers" and contained the following problems:

$\checkmark$ administrative influence - the regulator sets tariffs for all market participants;

$\downarrow$ restraining economic growth - a system of cross-subsidization: reduction of tariffs for the population at the expense of industry has led to a deterioration of the competitive position of industry;

$\checkmark$ lack of incentives for investment - setting tariffs based on the level of costs does not provide incentives to increase production efficiency and reduce costs. Competition mechanisms that should stimulate operational efficiency and investment in the development of the energy sector do not work.

The new open competitor market model can be depicted (Fig. 2).

The new model of the electricity market, which came into force on June 1, 2019, allows for free access to transport and distribution networks; a sufficient number of private energy companies in the market (producers and suppliers of electricity); an energy pricing mechanism that stimulates competition. 


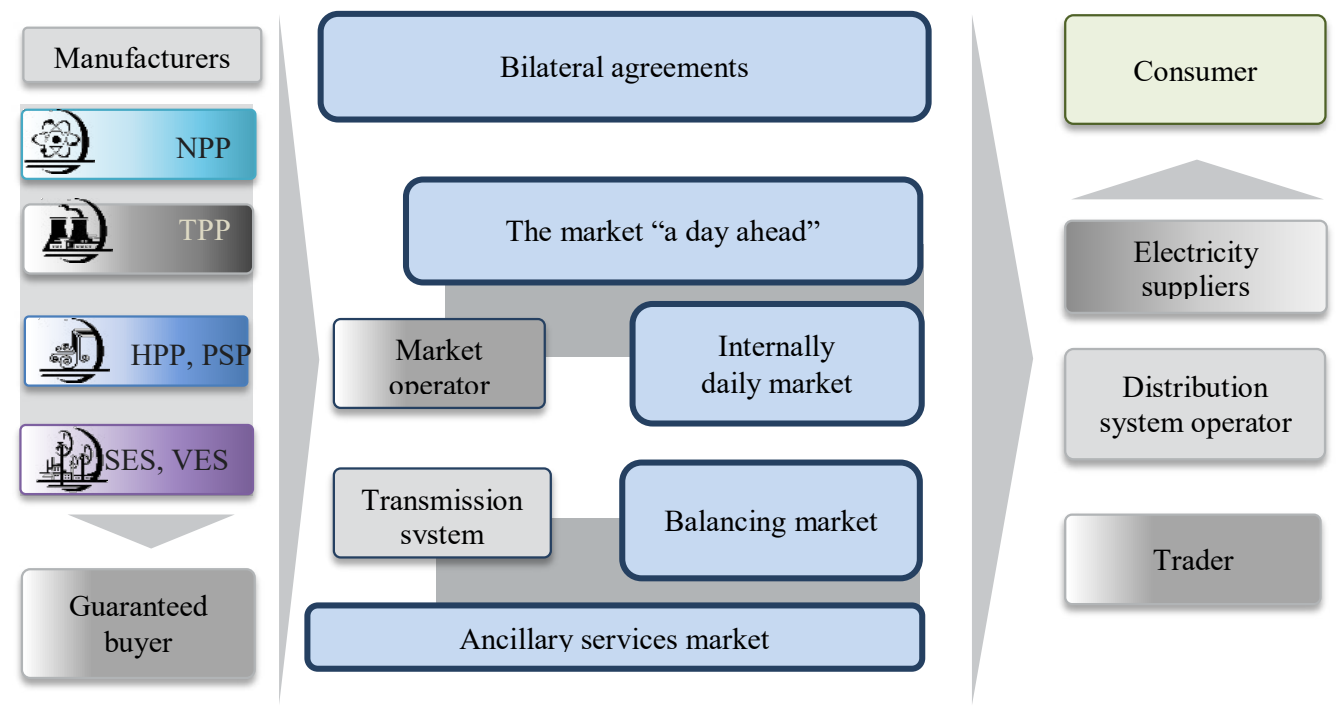

Fig. 2. Structure of segments of the new electricity market and its participants Source: own study based on Law of Ukraine "On the market of electrical energy"

Rys. 2. Struktura segmentów nowego rynku energii elektrycznej i jego uczestników

\section{Strategic development projects of the largest market player nuclear company}

The reforms reflected in the new Law on the Electricity Market and the Energy Strategy of Ukraine until 2035 contain the main vectors for the development of its operators - safety, efficiency and competitiveness, and affect each participating company. The most effective implementation of the reforms is the nuclear power generating company National Nuclear Energy Generating Company Energoatom (NNEGC Energoatom) (Doroshuk 2019), which covers more than half of the Ukrainian electricity generation market (Fig. 1).

In terms of installed NPP capacity and number of power units, NNEGC Energoatom ranks fifth in the world among the leading companies operating NPPs, and EDF, France ranks first (Fig. 3).

But the company has great production potential due to the possibility of increasing generally accepted factors like Nuclear Power Capacity Factor and Unit Readiness to carry the nominal electrical load Factor (the Ukrainian analog of Unit Capacity Factor) (Table 2).

In Figure 3 the compared values of the installed capacity of Water-Water Energetic Reactor (WWER) of the World Association of Nuclear Operators (WANO) in 2016 in Ukraine (15 power 


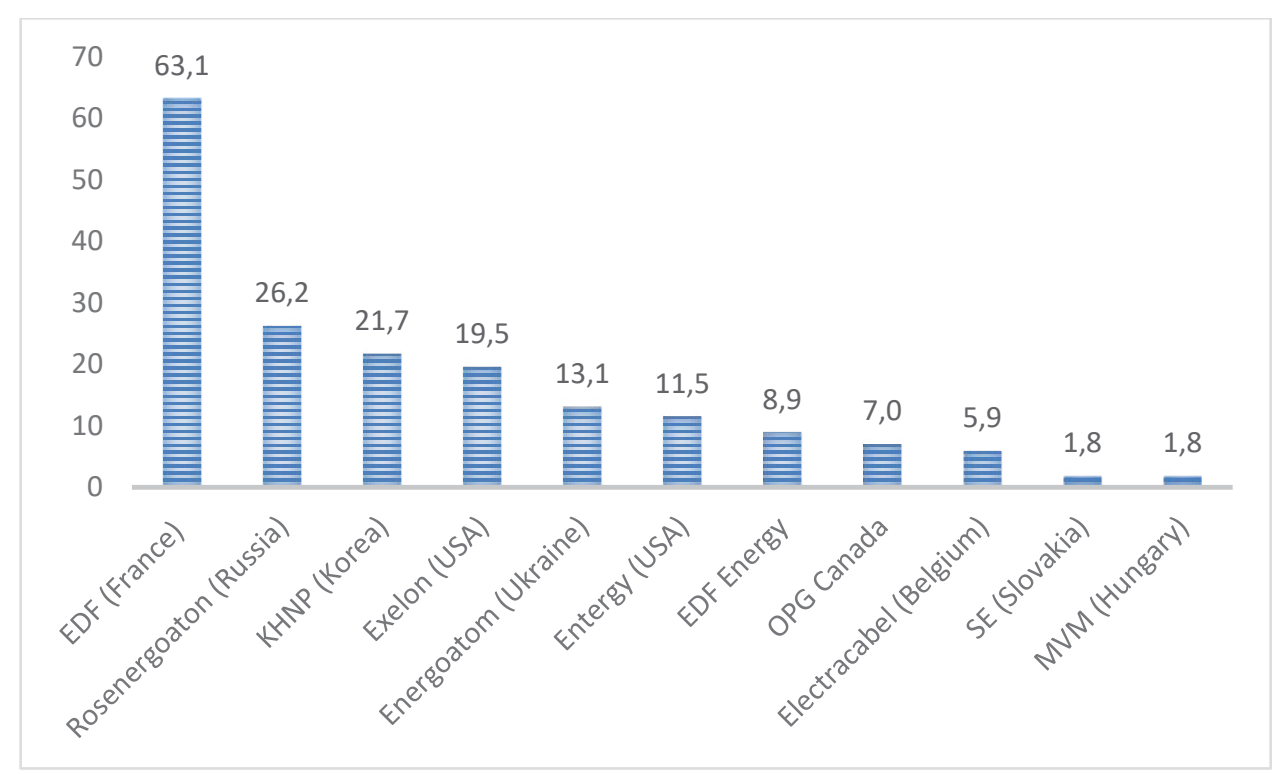

Fig. 3. Installed capacity of NNEGC Energoatom in comparison with other foreign energy companies [gigawatts] Source: own study based on Strategic plan of the state enterprise NNEGC Energoatom for 2018-2022

Rys. 3. Moc zainstalowana NNEGC Energoatom na tle innych zagranicznych koncernów energetycznych [gigawaty]

units of Ukrainian NPPs are highlighted in red columns.), Czech Republic, Romania, Bulgaria, Russia, Slovakia and others are shown. The median value of coefficient of installed capacity utilization for them is marked by a blue horizontal dashed line (value $87.53 \%$ ).

TABLE 2. Indicators of efficiency of power units of Ukrainian NPPs - Nuclear Power Capacity Factor and Unit Readiness to carry the nominal electrical load Factor of NPPs of NNEGC Energoatom

TABELA 2. Wskaźniki sprawności bloków elektrowni jądrowych Ukrainy - Współczynnik mocy jądrowej i gotowości bloku do przenoszenia nominalnego obciążenia elektrycznego

w NNEGC Energoatom

\begin{tabular}{|l|l|l|l|l|l|l|l|l|l|l|l|l|}
\hline \multicolumn{10}{|c|}{ Year } \\
\hline 2007 & 2008 & 2009 & 2010 & 2011 & 2012 & 2013 & 2014 & 2015 & 2016 & 2017 & 2018 & 2019 \\
\hline \multicolumn{10}{|c|}{ Nuclear Power Capacity Factor } \\
\hline 76.4 & 73.9 & 68.4 & 73.6 & 74.5 & 74.2 & 68.7 & 72.9 & 72.3 & 66.6 & 70.6 & 69.6 & 68.5 \\
\hline \multicolumn{10}{|c|}{ Unit Readiness to carry the nominal electrical load Factor } \\
\hline 78.0 & 78.3 & 76.8 & 78.7 & 78.2 & 77.5 & 78.0 & 79.4 & 78.2 & 71.8 & 76.1 & 70.2 & 69.8 \\
\hline
\end{tabular}

Source: own study based on Strategic plan of the state enterprise NNEGC Energoatom for 2018-2022, Technical and economic performance of NNEGC Energoatom in 2017, 2019. 
Only five power units in Ukraine exceed the median of WANO and only one block above the global median (Fig. 4). Thus, the problem of low Nuclear Power Capacity Factor of Ukraine is relevant and is one of the important issues of the company's development.

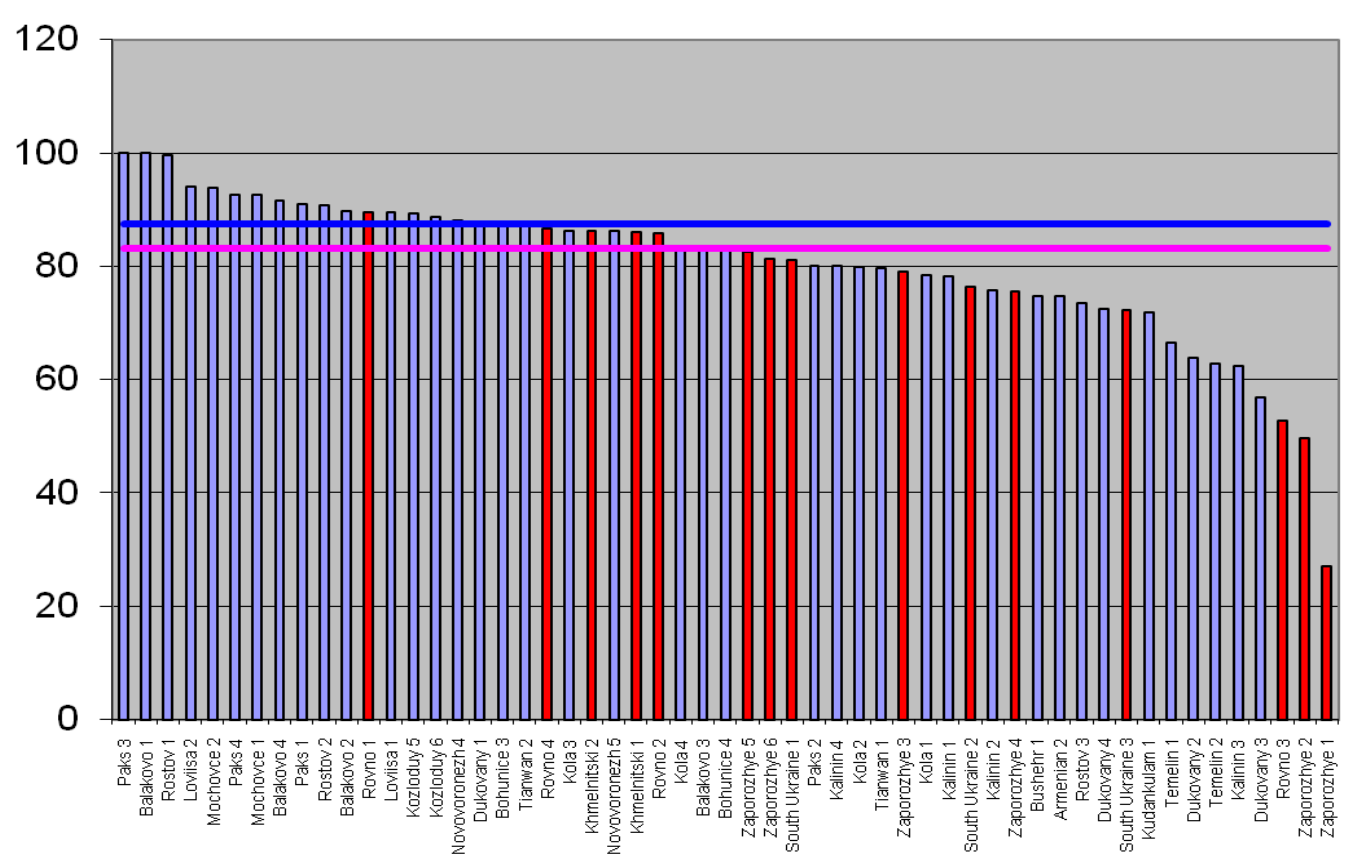

Fig. 4. Values of Nuclear Power Capacity Factor of WWER WANO reactors, 2016 Source: Nuclear electricity generation by country, World Association of Nuclear Operators

Rys. 4. Wartości współczynnika mocy jądrowej reaktorów WWER WANO, 2016 r.

In 2019, Energoatom generated 83 billion 228 million kWh of electricity, which according to operational data amounted to $101.8 \%$ of the planned target set for the company by the Government. The company also showed positive indicators in terms of the number of violations. In 2019, 13 violations were registered in the company's work, which is almost twice less than in 2018 - 22 violations. Most importantly, these violations led to only 5 unscheduled shutdowns of power units, which is almost three times less than in $2018-13$ shutdowns. Underproduction of electricity due to violations decreased 3.5 times -517 million kWh compared to 1.9 billion $\mathrm{kWh}$ in 2018. It is significant that this volume is less than the underproduced electricity due to dispatch and balance restrictions set by the operator of the transmission system of NEC Ukrenergo for Energoatom.

In terms of financial performance, the company has shown almost double growth. After all, according to operational data, in 2019 the company paid to the budgets of all levels of taxes, fees and insurance payments 19 billion 297 million UAH, which is 8 billion 605 million UAH or $80 \%$ 
more than in 2018. In 2019, the company became the only one in Ukraine to receive the highest level of corporate stability "AAA".

Further successful realization of the company's development potential largely depends on the implementation of the company's strategic projects (Fig. 5).

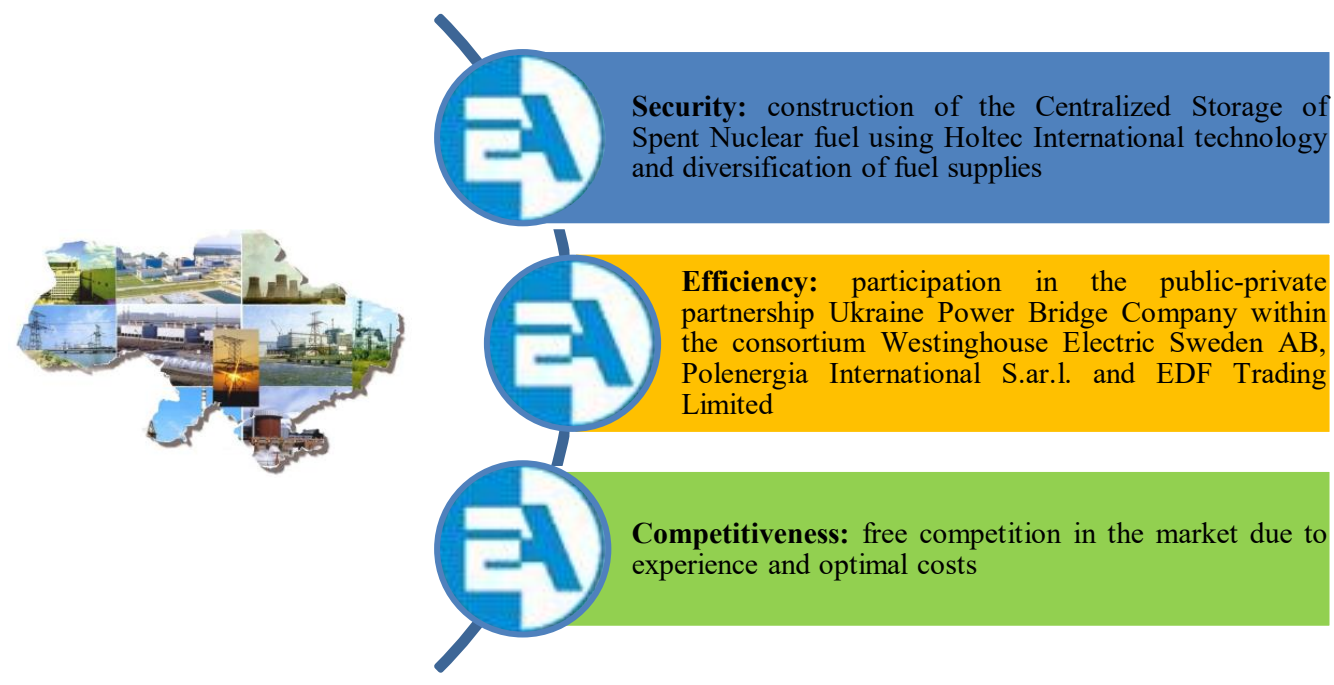

Fig. 5. Strategic projects of NNEGC Energoatom in the implementation of the new model of electricity market Source: own study

Rys. 5. Projekty strategiczne NNEGC Energoatom w zakresie wdrażania nowego modelu rynku energii elektrycznej

It is the main directions of the state's energy policy that form the basis for the implementation of strategic projects of the largest energy generating company in Ukraine, NNEGC Energoatom. Nuclear energy is first and foremost security, including the economic security of the country, so the priorities for the development of both domestic and world nuclear energy are the implementation of security projects. These projects are determined by the International Atomic Energy Agency on the basis of world experience in the operation of nuclear energy. For NNEGC Energoatom, the main strategic security projects are the construction of a Centralized Storage of Spent Nuclear Fuel using Holtec International technology and the diversification of fuel supplies to avoid dependence on one supplier country. In Ukraine, in 2018, Swedish-American fuel was loaded for the first time at the South-Ukrainian power unit, and in 2019, a permit for industrial operation was obtained.

Technical renewal of the energy sector requires investment, the sources of which in practice are own funds and international security programs, but this is not enough. A new form of funding is public-private partnerships, a successful example of which is the Ukraine-EU Energy Bridge, represented by the Ukraine Power Bridge Company as part of the Westinghouse Electric Sweden AB consortium, Polenergia International S.ar.l. and EDF Trading Limited. The efficiency of 
Ukrainian companies requires constant work due to the fact that labor productivity and return on assets in some cases are much lower than the world level. The success of change lies largely in how the company works on its business processes.

\section{Corporatization and change of the form of ownership of energy companies as part of the reform}

The issue of corporate governance is relatively new for both foreign and domestic economical and managerial thought. However, corporate governance is a determining factor in ensuring the investment attractiveness of the company, its ability to adapt to rapid changes in the internal and external environment.

The application of the principles of energy diplomacy and corporate governance at NNEGC Energoatom will overcome the shortcomings of the administrative approach that currently underlies the management, namely: over-regulation of personnel policy; bureaucratization of organizational structure; limited flexibility of operating activities; the need to coordinate business decisions with other administrative structures; distribution of non-core activities; significant limitations in pricing (Baillo et al. 2001).

It should be borne in mind that a fairly effective way to solve these problems by changing the form of ownership is sometimes unacceptable, as enterprises with the status of "strategically important for the economy and security of the country" are not a subject to privatization under Ukrainian law. This requires additional steps and the adoption of regulations in the process of corporatization.

For successful corporatization and rapid implementation of this process it is necessary to take the following steps:

$\downarrow$ specification of corporate rights and determination of institutional preconditions for their consolidation;

$\checkmark$ creating the necessary basis to avoid excessive influence on the management of the corporation and stakeholder groups;

$\checkmark$ harmonization of socio-economic interests of the owner of corporate rights (state) and stakeholders in such a way as to prevent abuse of economic power by shareholders, managers, stakeholders in the process of social distribution.

Corporatization can take more complex forms. Thus, in the process of corporatization there may be a possibility of vertical disintegration of the functions of the enterprise (depending on the situation) with their assignment to individual legal entities that have binding agreements with each other. The ability to enter into contracts and enforce them can contribute to greater transparency in the relationship between departments with different functions, especially in managing the cash flows needed to implement them. 
Currently, in the context of the country's structural energy reform, the issue of estimating the value of fixed assets of NNEGC Energoatom is becoming especially relevant. In a market economy, economic entities need to ensure compliance of the book value of assets with their market value, which is achieved through periodic revaluations (Order of the Ministry of Economic Development... 2017).

The process of corporatization of the enterprise, as a rule, takes place in four stages: preparatory, inventory, valuation of property that will be included in the authorized capital, and final. All these steps can be implemented thanks to a special law on the corporatization of the company. To date, the draft law has already been developed, but, in our opinion, it does not cover all the above processes.

The final stage of the process of corporatization and creation of a joint-stock corporation will be the approval of the charter of a public joint-stock company and state registration of termination of NNEGC Energoatom with the simultaneous state registration of the formed joint-stock company. Without this corporatization process, the company will not be able to be a full-fledged and independent player in the electricity market, the full-scale launch of which began on July 1 , 2020.

\section{New energy market model - challenges and solutions}

Liberalization of the electricity market in Ukraine is quite long-lasting, despite the fact that its main goal is to increase the efficiency of energy companies and ensure their investment attractiveness. Officially, the new market model has been operating for more than a year, the new market has five segments: the market of bilateral agreements, the market for the day ahead, the intraday market, the balancing market and the market of ancillary services. In fact, companies in a new market should get more freedom to do business, but in practice, unfortunately, this is not the case. Administrative restrictions in the form of special obligations are a violation of the principles of the market, which does not allow us to talk about fair competition or non-discriminatory pricing, which reflects the economically justified costs. The new market model in Ukraine has been operating for a little over a year, and, of course, this time is not enough to draw sound conclusions. However, it is possible to pre-assess the new working conditions, identify the main challenges and solutions:

$\downarrow$ transformation of energy legislation - a continuous process. And it is important not only to respond in a timely manner to changes in theregulations, but also to initiate them in order to protect market players and accelerate the implementation of the new model. The annual report of the Secretariat of the Energy Community states that Ukraine has set too high a level of Public Service Obligation for the state generation - NNEGC Energoatom and PJSC "Ukrhydnoenergo". Effective changes in Public Service Obligation should, on the one hand, protect against the shock of the country's economy and population due to rising electricity 
prices, and on the other hand, free up the necessary financial resources to increase the security of energy companies and implement the investment programs;

$\checkmark$ one of the positive features of the introduction of the new market model is not only to increase the profits of energy generating companies, but also to improve financial discipline in the energy market. If you do not take into account some delays in payment in the balancing market, the companies actually receive full payment for the electricity sold. However, the debt problem of the old energy market has been and remains the most acute. In particular, the debt of Energorynok to NNEGC Energoatom for the supplied electricity reached UAH 11.7 billion. The solution to this problem can be a debt repayment scheme, which will not only settle the receivables of energy companies, but also restructure their accounts payable to banking institutions, which will significantly improve the financial condition of the player company. Also, the solution to this problem may lie in the ban on the supply of electricity without paying for it. This primarily concerns water utilities and coal mines;

$\checkmark$ timely detection of signs of unfair competition is possible through an effective market monitoring mechanism by the regulator and the Antimonopoly Committee;

$\checkmark$ in the medium term it is extremely important to ensure full integration with the electricity markets of the EU - the Baltic States and Poland are promising foreign markets for Ukraine (Komorowska 2019; Korab 2011; Korab and Owczarek 2012; Motowidlak 2006). Without this, only at the expense of domestic resources, it will be almost impossible to provide sufficient liquidity and the desired economic effect of competition;

$\downarrow$ for the efficient functioning of the market, removing its main limitation is required - a huge cross-subsidization, which distorts the work of the market, although this will lead to an increase in tariffs for the population to an economically reasonable level.

\section{Conclusions}

Electricity market reform is not a one-time phenomenon, but a long-term process with the constant correction of inevitable mistakes and miscalculations. So far the market is very volatile and such volatility does not exactly help producers.

Ukraine has a developed electric power industry, which includes nuclear power, ranking fifth in the world, thermal, hydropower, solar and wind power. The drop in industrial output over the period from 2003 to 2018 led to a drop in electricity output from 180.4 to 159.4 billion $\mathrm{kWh}$. The positive aspects in this situation are the drop in electricity output mainly due to thermal energy, which leads to a decrease in carbon dioxide emissions and an improvement in the climate and the emergence of the possibility of selling electricity to other countries, in particular to Poland.

Since the summer of 2019, a new market model has started operating in Ukraine. The first year of work in the conditions of market liberalization made it possible to identify the need to 
develop new legislative and regulatory instruments regulating the activities of the electric power industry, the need to develop mechanisms for monitoring unfair competition and the fight against corruption, as well as the elimination of cross-subsidization, which violates the very principle of operation of a new electricity market.

Reforming the electric power industry is possible only in a close relationship between market liberalization and the reforms of energy companies, which is based on unbundling - the rejection of vertically oriented companies in favor of destroying monopolies and achieving free competition in the market. In practice, it looks like the corporatization of energy companies, which in Ukraine has successfully passed the initial stages. The article also shows a close connection between industry reforms and reforms of energy companies that implement strategic development projects to achieve safety, efficiency and competitiveness.

The successful process of change in the energy sector will be facilitated by a constructive dialogue between all participants in the process, as well as a combination of administrative methods and changes in the organizational culture of energy companies to translate the slogan "safety, efficiency, competitiveness" into practice.

\section{References}

Baillo et al. 2001 - Baillo, A.,Ventosa, M., Ramos, A., Rivier, M. and Canseco, A. 2001. Strategic unit commitment for generation companies in deregulated electricity markets. [In:] Hobbs, B., Rothkopf, M., O'Neil, R., Chao, H. (eds.) The Next Generation of Unit Commitment Models. Boston: Kluwer Academic Publishers, pp. 227-248.

Barroso et al. 2005 - Barroso, L.A., Cavalcanti, T.H., Purchala, K. and Giesbertz, P. 2005. Classification of Electricity Market Models Worldwide. IEEE, DOI: 10.1109/CIGRE.2005.1532720.

Bower, J. and BunN, D. 2000. Model-based comparisons of pool and bilateral markets for electricity. Energy Journal 21(3), pp. 1-29.

Cramton, P. and Ockenfels, A. 2012. Economics and Design of Capacity Markets for the Power Sector. Zeitschrift für Energiewirtschaft 36(2), pp. 113-134.

Doroshuk, H. 2019. Organizational development as a modern management tool for transformation of the company (case of Ukrainian energy company). Management 23(1), pp. 61-74.

Eid et al. 2016 - Eid, Ch., Bollinger, L.A., Koirala, B., Scholten, D., Facchinetti, E., Lilliestam, J. and HAKvoorT, R. 2016. Market integration of local energy systems: is local energy management compatible with European regulation for retail competition? Energy 114, pp. 913-922.

Energy strategy of Ukraine for the period up to 2035 "Safety, energy efficiency, competitiveness": approved by the Cabinet of Ministers of Ukraine from September 18, 2017. No. 605-r (Energetychna strategia Ukrainy na period do 2035 roku "Bezpeka, energoefektyvnist, konkurentospromozhnist": shvaleno pozporyadzhennyam Kabinetu Ministriv Ukrainy vid 18 serpnya 2017 r. No. 605-r). [Online] https:// zakon.rada.gov.ua/laws/file/text/58/f469391n10.pdf [Accessed: 2020-07-07] (in Ukrainian).

FrąCZEK, P. 2012. Selected aspects of energy policy modification in Sweden (Wybrane aspekty zmiany polityki energetycznej Szwecji). Polityka Energetyczna - Energy Policy Journal 15(3), pp. 198-209 (in Polish).

Green, R.J. and Newbery, D.M. 1992. Competition in the British electricity spot market. Journal of Political Economy 100(5), pp. 929-953. 
Hancher et al. 2015 - Hancher, L., De Hauteclocque, A. and Sadowska, M. 2015. Capacity Mechanisms in the EU Energy Market. Ed. 1. Oxford: Oxford University Press, 65 pp.

HogAn, W.W. 1997. A market power model with strategic interaction in electricity networks. Energy Journal 18(4), pp. 107-141.

Hunt, S. and Shuttleworth, G. 2004. Competition and Choice in Electricity. Hoboken NJ: John Wiley\&Sons Ltd.

Kirschen, D. and Strbac, G. 2004. Fundamental of Power System Economics. Hoboken NJ: John Wiley\&Sons Ltd.

Komorowska, A. 2019. Cross-border exchange of electricity between Poland and the neighboring countries. Polityka Energetyczna - Energy Policy Journal 22(4), pp. 37-52.

Korab, R. 2011. Possibilities of increasing the Polish cross-border transmission capacity. Przeglad Elektrotechniczny 87, pp. 87-90.

Korab, R. and OWCZAREK, R. 2012. Cross-border power flow control by using phase shifting transformers. Przegląd Elektrotechniczny 88, pp. 299-302.

KRZYKowsKi, M. 2009. The reform of community electric energy law (Reforma wspólnotowych rozwiazań prawnych $w$ zakresie elektroenergetyki). Polityka Energetyczna - Energy Policy Journal 12(2/2), pp. 307-318 (in Polish).

KuCHARSKa, A. 2017. 15 years after the liberalization of the energy market in Austria (15 lat po liberalizacji rynku energii w Austrii - ewolucja i perspektywy). Polityka Energetyczna - Energy Policy Journal 20(1), pp. 83-102 (in Polish).

Law of Ukraine "On the market of electrical energy" (Zakon Ukrainy pro rynek elektroenergii). [Online] https://zakon.rada.gov.ua/laws/show/2019-19\#Text [Accessed: 2020-07-07] (in Ukrainian).

Macroeconomic indicators. National Bank of Ukraine (Makroekonomichni pokaznyki. Natsionalnyy Bank Ukrainy). [Online] https://bank.gov.ua/ua/statistic/macro-indicators [Accessed: 2020-07-07] (in Ukrainian).

Malko, J. 2014. Generation, Transmission, and Distribution Case Study: Europe (Studium przypadku: Europa - generacja, przesyl, dystrybucja). Polityka Energetyczna - Energy Policy Journal 17(3), pp. 157-168 (in Polish).

Malko, J. 2015. Europe: View from America Case Study: Electric power system (Europa widziana z Ameryki. Case study: elektroenergetyka). Polityka Energetyczna - Energy Policy Journal 18(3), pp. 15-24 (in Polish).

Michalski, D. and Soltysik, M. 2016. The Next Step in Development of European Power Market - Capacity Market. Unia Europejska 3, pp. 49-60.

Motowidlak, T. 2006. Cross-border connections as part of the single European electricity market. Elektroenergetyka 3, pp. 20-60.

Nuclear electricity generation by country. World Nuclear Association. [Online] http://www.world-nuclear. org [Accessed: 2020-07-07].

Order of the Ministry of Economic Development and Trade of January 24, 2017 №81 "On approval of the list of state enterprises belonging to the sphere of management of the Ministry of Energy and Coal Industry of Ukraine, which are subject to transformation into state joint stock companies" (Nakaz Ministerstva ekonomichnogo rozvytku i torgivli vid 24 sichnya 2017 roku No. 81 "Pro zatverdzhennya pereliku derzhavny hidpryemstv, scho nalezhat do cfery upravlinnya Ministerstva energetyky i vugolnoyi promyslovosti, yaki pidlyagayut peretvorennyu v derzhavni aktsionerni tovarystva"). [Online] http:// search.ligazakon.ua/1_doc2.nsf/link1/ME170108.html [Accessed: 2020-07-07] (in Ukrainian).

PoPŁaWSKi, P. 2012. The problem of constructing a model for the long-term forecast of electricity demand in Poland (Problematyka budowy modelu dlugoterminowej prognozy zapotrzebowania na energię elektryczna dla Polski). Polityka Energetyczna - Energy Policy Journal 15(3), pp. 293-304 (in Polish). 
Power plant capacity and electricity generation (Potuzhnist elektrostantsiy ta vyrobnytstvo elektroenergii). [Online] http://www.ukrstat.gov.ua/operativ/operativ2012/pr/etgv/etgv_u/ele_ve_11u.html [Accessed: 2020-07-07] (in Ukrainian).

Sencar et al. 2014 - Sencar, M., Pozeb, V. and Krope, T. 2014. Development of EU (European Union) energy market agenda and security of supply. Energy 77(1), pp. 117-124.

Sтоғт, S. 2003. Power System Economics Designing Markets for Electricity. Hoboken NJ: Wiley Interscience.

Strategic plan of the state enterprise "NNEGC Energoatom for 2018-2022 (Strategichnyy plan derzhavnogo pidpryemstva "Natsionalna atomna energogeneruucha compania "Energoatom" na 2018-2022 roky). [Online] http://www.energoatom.com.ua/files/file/strateg_chniy_plan_2018_2022_04042018. pdf [Accessed: 2020-07-07] (in Ukrainian).

Technical and economic performance of NNEGC Energoatom in 2017 (Tehniko-ekomimichni pokaznyki roboty DP "NAEK “Energoatom” za 2017 rik). [Online] http://www.energoatom.com.ua/files/file/ tep_12_2017_balans.pdf [Accessed: 2020-07-07] (in Ukrainian).

Technical and economic performance of NNEGC Energoatom in 2019 (Tehniko-ekomimichni pokaznyki roboty DP “NAEK “Energoatom” za 2019 rik). [Online] http://www.energoatom.com.ua/uploads/2020/ TEP_2019_new.pdf [Accessed: 2020-07-07] (in Ukrainian).

Third energy package. [Online] https://ec.europa.eu/energy/topics/markets-and-consumers/market-legislation/third-energy-package_en [Accessed: 2020-08-25].

World Association of Nuclear Operators. [Online] https://new.wanomc.ru [Accessed: 2020-07-07] (in Ukrainian).

\title{
Reforma sektora elektroenergetycznego na Ukrainie - liberalizacja rynku i korporatyzacja przedsiębiorstw
}

\author{
Streszczenie
}

Energetyka jest podstawową gałęzią gospodarki i zapewnia bezpieczeństwo kraju, w tym ekonomiczne. Celem artykułu jest analiza reformy sektora energetycznego na Ukrainie pod kątem pomyślnej integracji z sektorem energetycznym Unii Europejskiej. Analizie poddano sektor energetyczny Ukrainy w latach 2003-2018. Zidentyfikowano następujące główne przyczyny spadku produkcji energii eletrycznej na Ukrainie - spadek wielkości produkcji związany z aneksją Krymu i operacją antyterrorystyczną na wschodzie Ukrainy, spadek wielkości produkcji energii z elektrociepłowni ze względu na starzenie się mocy produkcyjnych, trudności z surowcami, niską sprawność, co jednak ma dobry wpływ na środowisko ze względu na zmniejszenie emisji dwutlenku węgla. Kierunki reformy elektroenergetyki Ukrainy rozważane są w kontekście „,przedsiębiorstwo-przemysł-rynek”. Analizie poddano cztery modele rynku energii elektrycznej i uzasadniono nowy model konkurencyjnego rynku energii elektrycznej na Ukrainie z rynkiem kontraktowym, rynkiem spot i rynkiem bilansującym. Zaproponowano strukturę segmentów nowego 
rynku energii elektrycznej i uczestników. Ponad połowę rynku energii elektrycznej zapewnia energetyka jądrowa, która zajmuje piąte miejsce na świecie pod względem zainstalowanej mocy. Analiza wskaźników efektywności spółki jądrowej w latach 2007-2019 wykazała znaczne rezerwy umożliwiając jej rozwój, które są z powodzeniem wdrażane poprzez strategiczne projekty rozwojowe i stopniową korporatyzację spółki jako narzędzia unbundlingu. Przeanalizowano główne wyzwania związane z wdrożeniem nowego modelu rynku oraz zaproponowano innowacyjne rozwiązania.

SŁoWA KLUCZOWE: model rynku energii elektrycznej, liberalizacja rynku energii elektrycznej, korporatyzacja przedsiębiorstw energetycznych, unbundling 